\title{
The migration and transformation of chromium during co-processing of cement raw meal mixed with chrome-polluted soil
}

\section{Haiping Xiao}

North China Electric Power University - Beijing Campus: North China Electric Power University Yan Li

North China Electric Power University - Beijing Campus: North China Electric Power University

\section{Mingwei Wang}

North China Electric Power University - Beijing Campus: North China Electric Power University

Dahai Yan ( $\nabla$ seavsland@163.com )

Chinese Research Academy of Environmental Sciences https://orcid.org/0000-0001-5079-0707

\section{Zhong Liu}

North China Electric Power University - Beijing Campus: North China Electric Power University

\section{Research Article}

Keywords: Chromium, Cement kiln, Chrome-polluted soil, Co-processing, migration, valence

Posted Date: February 11th, 2021

DOl: https://doi.org/10.21203/rs.3.rs-217639/v1

License: (c) (1) This work is licensed under a Creative Commons Attribution 4.0 International License. Read Full License

Version of Record: A version of this preprint was published at Environmental Technology \& Innovation on November 1st, 2021. See the published version at https://doi.org/10.1016/j.eti.2021.101971. 


\section{2 of cement raw meal mixed with chrome-polluted soil}

3 Haiping Xiao ${ }^{\mathrm{a}}$, Yan $\mathrm{Li}^{\mathrm{a}}$, Mingwei Wang ${ }^{\mathrm{a}}$, Dahai Yan ${ }^{\mathrm{b} *}$, Zhong $\mathrm{Liu}^{\mathrm{a}}$

${ }^{a}$ School of Energy, Power and Mechanical Engineering, North China Electric Power University, Beijing 102206, China

${ }^{\mathrm{b}}$ State Key Laboratory of Environmental Criteria and Risk Assessment, Chinese Research Academy of Environmental Sciences, Beijing 100012, China

* Corresponding author. E-mail address: seavsland@163.com; Tel.: 86-15901376037; Fax: 8610-84913903

Abstract: To efficiently dispose of chrome-polluted soil, we tested the co-processing of raw meal mixed with chrome-polluted soil in a tube furnace (laboratory experiments) and a cement rotary kiln (field-scale experiments). The migration and transformation reactions of chromium were analyzed and the environmental risk was evaluated. The average mass balance value was $91 \%$ for the laboratory experiments. In field-scale experiments, the mass balance values were $110 \%$ for the control experiments and $84 \%$ when $1 \%$ soil was treated. Therefore, only a small amount of $\mathrm{Cr}$ was volatilized into the flue gas. The average total $\mathrm{Cr}$ concentration in the soil samples was 403.25 $\mathrm{mg} / \mathrm{kg}$, and the ratio of $\mathrm{Cr}(\mathrm{VI})$ to total $\mathrm{Cr}$ was $1.83 \%$ or less. On average, $45.15 \%$ of $\mathrm{Cr}(\mathrm{III})$ was oxidized to $\mathrm{Cr}(\mathrm{VI})$ in laboratory experiments, while $87.94 \%$ of $\mathrm{Cr}(\mathrm{III})$ was oxidized in field-scale experiments, and the difference could be a result of the different calcination conditions. The materials in the cement rotary kiln make full contact with oxygen, and in this high temperature and oxidizing atmosphere, abundant $\mathrm{CaO}$ and $\mathrm{MgO}$ promote the oxidation of $\mathrm{Cr}(\mathrm{III})$ to $\mathrm{CaCrO}_{4}$. $\mathrm{SiO}_{2}$, $\mathrm{Al}_{2} \mathrm{O}_{3}$, and $\mathrm{Fe}_{2} \mathrm{O}_{3}$ reduce $\mathrm{CaCrO}_{4}$, which inhibits $\mathrm{Cr}(\mathrm{III})$ oxidation. The $\mathrm{Cr}$ concentration in the cement products was well below the Chinese standard limits. Therefore, the treatment of $1 \%$ chrome-polluted soil with a cement rotary kiln is experimentally safe.

Keywords: Chromium, Cement kiln, Chrome-polluted soil, Co-processing, migration, valence

\section{Introduction}

Chromium is widely used in steel, leather, and other industries, and the resulting chromium residue can cause serious pollution. In China, the annual production of chromium exceeds 160,000 tonnes, the cumulative amount of chromium residue is nearly six million tonnes, and the amount of chrome-polluted soil exceeds 20 million tonnes(Wang et al. 2011). Cement kilns have some advantages for the co-processing of solid waste, and can increase the capacity for solid waste disposal and reduce the consumption of raw materials and fuel by the cement industry(Aranda Usón et al. 2013; Kosajan et al. 2020). However, the migration and transformation of $\mathrm{Cr}$ and other heavy metals during co-processing can threaten environmental and human health. Most chromium residue is in the trivalent $(\mathrm{Cr}(\mathrm{III}))$ and the highly toxic hexavalent $(\mathrm{Cr}(\mathrm{VI}))$ forms. More importantly, some $\mathrm{Cr}$ (III) will be oxidized to $\mathrm{Cr}(\mathrm{VI})$ during co-processing in a cement kiln(Fu et al. 2021; Gong et al. 2020; Li et al. 2018a). Therefore, the study of the transfer and transformations of Cr during coprocessing of waste is of great significance.

Alkali metal and alkali earth metal oxides affect the redox state of chromium. In cement raw meal, coal, and chrome-polluted soil, chromium exists mainly in the forms $\mathrm{CaCr}_{2} \mathrm{O}_{4}, \mathrm{Cr}(\mathrm{OH})_{3}$, 
$\mathrm{Cr}_{2} \mathrm{O}_{3}, \mathrm{Cr}_{2}\left(\mathrm{SO}_{4}\right)_{3}, \mathrm{CrO}_{3}$, and $\mathrm{FeCr}_{2} \mathrm{O}_{4}$.(Jiang et al. 2016) The components in cement raw meal include $\mathrm{CaO}, \mathrm{SiO}_{2}, \mathrm{Al}_{2} \mathrm{O}_{3}, \mathrm{Fe}_{2} \mathrm{O}_{3}$, and $\mathrm{MgO}$; $\mathrm{CaO}$ makes up more than $60 \%$ of the raw meal $(\mathrm{Li}$ 2020).

Together, $\mathrm{CaO}$ and oxygen will oxidize $\mathrm{Cr}(\mathrm{III})$ to $\mathrm{Cr}(\mathrm{VI})$, while only oxygen, at even $1500{ }^{\circ} \mathrm{C}$, will not oxidize $\mathrm{Cr}(\mathrm{III})$. Lack of oxygen can inhibit the oxidation of $\mathrm{Cr}(\mathrm{III})$ to $\mathrm{Cr}(\mathrm{VI})$ (Kavouras et al. 2015; Verbinnen et al. 2013). $\mathrm{CaO}$ is converted to $\mathrm{Ca}^{0}$ by assisting the electron transfer from $\mathrm{Cr}$ (III) to $\mathrm{O}_{2}$, and $\mathrm{Ca}^{0}$ is then oxidized by $\mathrm{O}_{2}$ to $\mathrm{Ca}^{2+}$ (Chen et al. 2012; Chen et al. 2013). During combustion of chromium-rich tannery sludge in an air atmosphere, the x-ray diffraction patterns indicate that $\mathrm{CaCrO}_{4}$ first appears at $400{ }^{\circ} \mathrm{C}$, gradually increases in the range of $400-800{ }^{\circ} \mathrm{C}$, and reaches a maximum concentration at $800{ }^{\circ} \mathrm{C}$ (Yang et al. 2020a). $\mathrm{Cr}_{2} \mathrm{O}_{3}$ and $\mathrm{CaO}$ were heated in a muffle furnace. The X-ray adsorption near-edge spectroscopy spectra indicated that the initial oxidation of $\mathrm{Cr}_{2} \mathrm{O}_{3}$ occurred at approximately $700{ }^{\circ} \mathrm{C}$, and the intensity of the $\mathrm{Cr}(\mathrm{VI})$ peak increased dramatically with increasing temperature(Chen et al. 2013; Hu et al. 2018). During the heating process, $\mathrm{CaCr}_{2} \mathrm{O}_{4}$ is formed as an intermediate product, and the oxidation of $\mathrm{CaCr}_{2} \mathrm{O}_{4}$ is favored with increasing free $\mathrm{Ca}(\mathrm{Hu}$ et al. 2018). In addition, $\mathrm{CaO}$ can capture $\mathrm{Cr}$ steam to form calcium chromite, thereby inhibiting $\mathrm{Cr}$ volatilization and promoting $\mathrm{Cr}$ enrichment in solid products(Chen et al. 2013). $\mathrm{SiO}_{2}$ is an acidic oxide that can combine with $\mathrm{O}^{2-}$, while $\mathrm{Al}_{2} \mathrm{O}_{3}$ and $\mathrm{Fe}_{2} \mathrm{O}_{3}$ are neutral oxides that can absorb $\mathrm{O}^{2-}$ under basic conditions. Therefore, $\mathrm{SiO}_{2}, \mathrm{Al}_{2} \mathrm{O}_{3}$, and $\mathrm{Fe}_{2} \mathrm{O}_{3}$ reduce $\mathrm{CaCrO}_{4}$ to form silicate, aluminate, and ferrite, respectively, and thereby inhibit the oxidation of $\mathrm{Cr}(\mathrm{III})(\mathrm{Mao}$ et al. 2016; Wang et al. 2014). $\mathrm{SiO}_{2}$ and $\mathrm{Al}_{2} \mathrm{O}_{3}$ favor the capture of $\mathrm{Cr}$ vapor, especially when the ratio of $\mathrm{Si}: \mathrm{Al}$ is $3: 1 . \mathrm{Fe}_{2} \mathrm{O}_{3}$ can capture $\mathrm{Cr}$ steam to form chromite, but the efficiency of this reaction is much lower than for the $\mathrm{CaO}$ reaction(Wang et al. 2012; Yang et al. 2020b). Therefore, in the process of co-processing solid waste in a cement kiln, oxides that are present in high concentrations in the cement raw meal will have a greater impact on the oxidation of $\mathrm{Cr}(\mathrm{III})$.

Fan et al.(Fan et al. 2014) explored the transformation of $\mathrm{Cr}$ in a cement kiln co-processing solid waste by adding $\mathrm{Na}_{2} \mathrm{CrO}_{4}$ to the raw meal and calcining in a tube furnace. Chen et al.(Chen et al. 2013) studied the reaction thermodynamics of $\mathrm{Cr}$-doped coal mixed with $\mathrm{CaO}, \mathrm{Fe}_{2} \mathrm{O}_{3}$, or $\mathrm{MgO}$ during the combustion process in a lab-scale drop-tube furnace. Yang et al.(Yang et al. 2020a) studied the transformation of chromium after calcining chrome-rich tanning sludge in a crucible. Many studies have investigated the transformation of $\mathrm{Cr}$ at the laboratory scale, however few studies exist on the transfer and transformation of $\mathrm{Cr}$ during co-processing of solid waste in a cement plant.

In this study, the cement raw meal was mixed with $1 \%, 3 \%$, and $5 \%$ chrome-polluted soil, and the mixture was calcined at high temperature in a tube furnace. Based on the results from the laboratory experiments, field-scale experiments involving co-processing of chrome-polluted soil were carried out in a cement rotary kiln. This research will provide reference data and a theoretical basis for the development of co-processing solid waste technology.

\section{Materials and Methods}

\subsection{Materials}

Raw meal, clinker, coal, and cement were collected from a cement plant. Seven chromepolluted soils, having different degrees of pollution, were collected from the original site of the Chongqing Special Steel Plant. The total $\mathrm{Cr}$ concentration was measured according to "Determination of metal elements in solid waste by inductively coupled plasma-mass spectrometry (ICP-MS)" from HJ 766-2015. The Cr(VI) concentration was measured according to 
"Determination of alkali dissolution of solid waste from hexavalent chromium/flame atomic absorption spectrophotometry" and the United States Environmental Protection Agency Method 3060 “Alkaline Digestion for Hexavalent Chromium."

Cement raw meal was composed of calcareous and clayey solids and a small amount of calibration material. The soil was composed mainly of silico-aluminates and oxides. The chromepolluted soil was air-dried and ground. After grinding, it was passed through a 100 mesh sieve and dried in a blast drying oven at $110{ }^{\circ} \mathrm{C}$ for $2 \mathrm{~h}$. The raw materials included the oxides $\mathrm{CaO}, \mathrm{SiO}_{2}$, $\mathrm{Al}_{2} \mathrm{O}_{3}, \mathrm{Fe}_{2} \mathrm{O}_{3}$, and $\mathrm{MgO}$. The properties of the raw materials are listed in Table 1(Li 2020; Li et al. 2009).

Table 1 General properties of raw meal and soil components

\begin{tabular}{lll}
\hline & Raw meal & Soil \\
\hline Ignition loss & $35.48 \%$ & $8.18 \%$ \\
$\mathrm{CaO}$ & $43.54 \%$ & $5.05 \%$ \\
$\mathrm{SiO}_{2}$ & $13.08 \%$ & $63.30 \%$ \\
$\mathrm{Al}_{2} \mathrm{O}_{3}$ & $3.57 \%$ & $11.90 \%$ \\
$\mathrm{Fe}_{2} \mathrm{O}_{3}$ & $1.40 \%$ & $4.90 \%$ \\
$\mathrm{MgO}$ & $1.03 \%$ & $2.40 \%$ \\
Else & $1.89 \%$ & $4.27 \%$ \\
\hline
\end{tabular}

\subsection{Laboratory experiments}

\subsubsection{Calcination experiments in a tube furnace}

The raw meal was mixed with $1 \%, 3 \%$, or $5 \%$ chrome-polluted soil. The mixtures were thoroughly homogenized, and 20-30 g was placed in a quartz crucible. The crucibles were preheated on the top of a tube furnace, and then were placed in the furnace for $30 \mathrm{~min}$. Two crucibles were put into the furnace for each run, and calcination experiments were carried out twice for each mixing ratio. The experiments were carried out in an atmosphere of $\mathrm{O}_{2}(5 \%)$ and $\mathrm{N}_{2}(95 \%)$ with the flow rate of $1 \mathrm{~L} / \mathrm{min}$, and the temperature was set at $1450{ }^{\circ} \mathrm{C}$. The mass of the samples was accurately weighed before and after the experiments.

\subsection{Field-scale experiments}

\subsubsection{Co-processing chrome-polluted soil in a cement rotary kiln}

The field-scale experiments were carried out in a cement rotary kiln. The mixing of raw meal and chrome-polluted soil was conducted at various mass ratios indicated in Table 2.

Table 2 Material parameters under two working conditions $(\mathrm{t} / \mathrm{h})$

\begin{tabular}{ccccc}
\hline $\begin{array}{c}\text { Working } \\
\text { condition }\end{array}$ & $\begin{array}{c}\text { Chrome- } \\
\text { polluted soil }\end{array}$ & Raw meal & Coal & Clinker \\
\hline Control & 0 & 180 & 16.8 & 111.8 \\
Add $1 \%$ soil & 1.8 & 180 & 16.8 & 111.8 \\
\hline
\end{tabular}

\subsubsection{Cement kiln system}

A schematic of the cement kiln calcining system is illustrated in Fig.1. The chrome-polluted soil was added to the raw mill, which homogenized the soil and raw meal. 


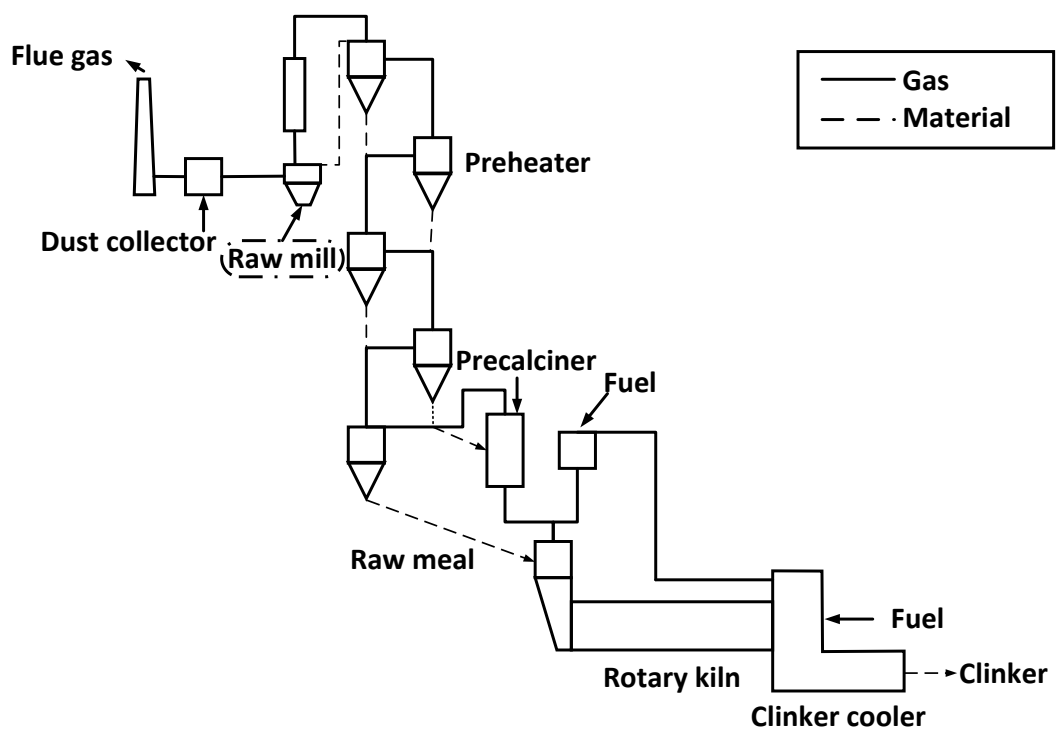

Fig.1 Schematic diagram of a cement kiln system

\section{Results and Discussion}

\subsection{Laboratory experiments}

\subsubsection{Cr in chrome-polluted soil}

Table 3 shows the distribution of $\mathrm{Cr}$ in the seven chrome-polluted soils. All samples were tested in parallel ( $\mathrm{a}$ and $\mathrm{b}$ ). The concentration of $\mathrm{Cr}$ (III) was calculated according to Eq. (1), where $\omega$ refers to the $\mathrm{Cr}(\mathrm{III})$ concentration. The average total $\mathrm{Cr}$ concentration in the samples was $403.25 \mathrm{mg} / \mathrm{kg}$, and the average $\mathrm{Cr}(\mathrm{VI})$ concentration was $2.12 \mathrm{mg} / \mathrm{kg}$. The ratio of $\mathrm{Cr}(\mathrm{VI})$ to total $\mathrm{Cr}$ was $1.83 \%$ or less. The soil sample used in the experiments was sample No.7 because it contained the most $\mathrm{Cr}$.

$$
\omega\left(C r^{3+}\right)=\omega\left(C r_{\text {total }}\right)-\omega\left(C r^{6+}\right)
$$

Table 3 The distribution of $\mathrm{Cr}$ in chrome-polluted soils $(\mathrm{mg} / \mathrm{kg})$

\begin{tabular}{llll}
\hline Samples of soils & $\omega\left(\mathrm{Cr}_{\text {total }}\right)$ & $\omega\left(\mathrm{Cr}^{6+}\right)$ & $\omega\left(\mathrm{Cr}^{3+}\right)$ \\
\hline $1 \mathrm{a}$ & 416.40 & 4.20 & 412.19 \\
$1 \mathrm{~b}$ & 421.79 & 1.90 & 419.89 \\
$2 \mathrm{a}$ & 385.56 & 0.81 & 384.75 \\
$2 \mathrm{~b}$ & 408.91 & - & 408.91 \\
$3 \mathrm{a}$ & 339.85 & 1.25 & 338.61 \\
$3 \mathrm{~b}$ & 329.63 & - & 329.63 \\
$4 \mathrm{a}$ & 123.44 & 2.26 & 121.18 \\
$4 \mathrm{~b}$ & 130.48 & 0.76 & 129.72 \\
$5 \mathrm{a}$ & 325.65 & 1.01 & 324.64 \\
$5 \mathrm{~b}$ & 354.61 & - & 354.61 \\
$6 \mathrm{a}$ & 445.22 & 1.38 & 443.85 \\
$6 \mathrm{~b}$ & 440.56 & 7.72 & 432.84 \\
$7 \mathrm{a}$ & 806.00 & 4.44 & 801.56 \\
\hline
\end{tabular}




\subsubsection{Mass balance of $\mathrm{Cr}$}

Calcination experiments of raw meal and chrome-polluted soil were performed in a tube furnace. The raw materials included cement raw meal and soil, and the combustion products included clinker and flue gas. The mass and the total $\mathrm{Cr}$ concentration of these substances are listed in Tables 4 and 5, respectively. The total Cr concentration in clinker was 1.52-4.67 times of that in raw meal, and increased with the mixing ratio of soil. The total $\mathrm{Cr}$ concentration in clinker increased under the influence of weight loss. The rate of weight loss in the calcination experiments ranged from $35.02 \%$ to $36.27 \%$, and was caused by the evaporation of crystalline water, the release of $\mathrm{CO}_{2}$ and $\mathrm{SO}_{2}$, and the loss of organic impurities.

Table 4 The mass of raw materials and products $(\mathrm{g})$

\begin{tabular}{llll}
\hline \multirow{2}{*}{$\begin{array}{c}\text { Working } \\
\text { conditions }\end{array}$} & \multicolumn{2}{l}{ Raw materials } & Products \\
\cline { 2 - 4 } & Raw meal & Soil & Clinker \\
\hline Control & 32.19 & - & 17.83 \\
Add 1\% soil & 24.98 & 0.25 & 16.11 \\
Add 3\% soil & 25.22 & 0.78 & 14.74 \\
Add 5\% soil & 24.39 & 1.28 & 15.57 \\
\hline
\end{tabular}

Table 5 The total Cr concentration in raw materials and products $(\mathrm{mg} / \mathrm{kg})$

\begin{tabular}{clll}
\hline \multirow{2}{*}{$\begin{array}{c}\text { Working } \\
\text { conditions }\end{array}$} & \multicolumn{2}{l}{ Raw materials } & Products \\
\cline { 2 - 4 } & Raw meal & Soil & Clinker \\
\hline Control & 16.33 & - & 24.87 \\
Add 1\% soil & 15.10 & 761.67 & 34.88 \\
Add 3\% soil & 12.80 & 761.67 & 54.06 \\
Add 5\% soil & 19.18 & 761.67 & 85.70 \\
\hline
\end{tabular}

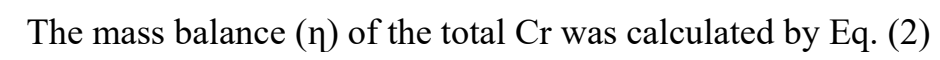

$$
\eta=\frac{M_{c l} \cdot C_{c l}}{M_{r m} \cdot C_{r m}+M_{s} \cdot C_{s}} \times 100 \%
$$

Where $M_{r m}, M_{s}$, and $M_{c l}$ represent the mass of raw meal, soil, and clinker, respectively. $C_{r m}, C_{s}$, and $\mathrm{C}_{\mathrm{cl}}$ represent the total $\mathrm{Cr}$ concentration in each of these three materials. The mass balance rate of $\mathrm{Cr}$ under the four working conditions is shown in Fig.2. The average mass balance value was $91 \%$, with a range of $70 \%$ to $130 \%$ over all the experiments. 


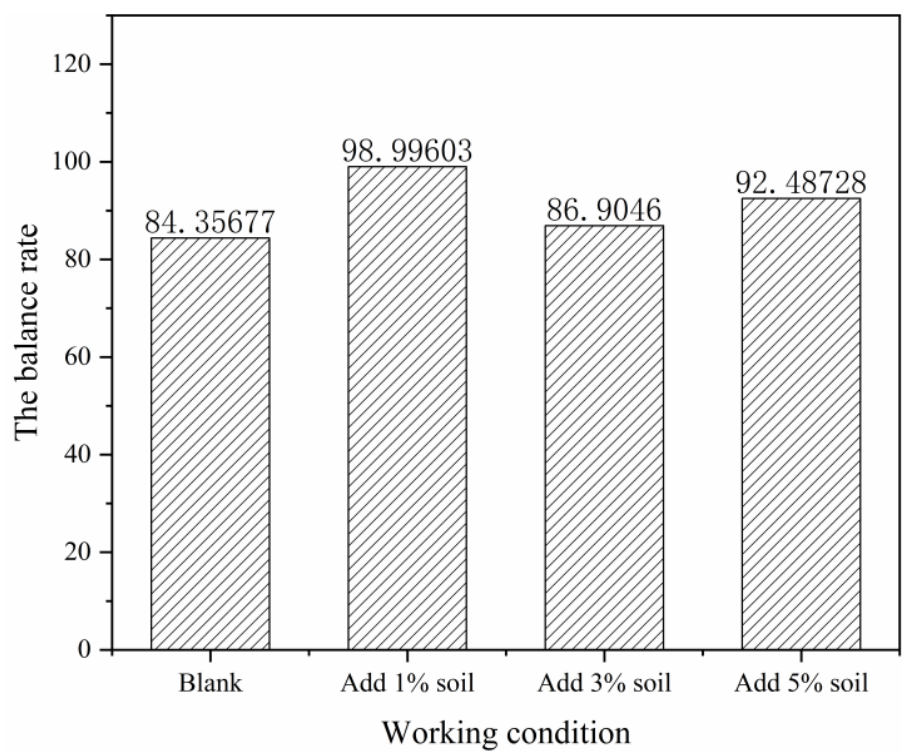

Fig.2 The mass balance value for $\mathrm{Cr}$ under different experimental conditions

No chromium was detected in the flue gas. Chromium belongs to an elemental group between the volatile and low volatility heavy metals. Chromium compounds include organic and inorganic forms, and organic chromium is more volatile. The cement raw meal is mainly composed of calcareous and clayey materials. Chromium is predicted to exist mainly in an inorganic form, such as $\mathrm{CaCr}_{2} \mathrm{O}_{4}, \mathrm{Cr}(\mathrm{OH})_{3}, \mathrm{Cr}_{2} \mathrm{O}_{3}, \mathrm{FeCr}_{2} \mathrm{O}_{4}$, or their complexes(Jiang et al. 2016). Chrome-polluted soils were collected from the original site of a special steel plant, and chromium is predicted to exist as $\mathrm{Cr}_{2}\left(\mathrm{SO}_{4}\right)_{3}$ and $\mathrm{CrO}_{3}$. Therefore, most of chromium in the raw materials will be difficult to volatilize.

Chromium is volatilized mainly as a hydroxide in a high-temperature tube furnace. Thermodynamically stable $\mathrm{Cr}$ compounds include $\mathrm{CrO}_{3}(\mathrm{~g}), \mathrm{CrOOH}(\mathrm{g})$, and $\mathrm{CrO}_{2}(\mathrm{OH})_{2}(\mathrm{~g})($ Nowak et al. 2012; Roy et al. 2013; Świetlik et al. 2014). Ryszard et al.(Świetlik et al. 2014) found that $\mathrm{CrOOH}$ and $\mathrm{CrO}_{2}(\mathrm{OH})_{2}$ were the main gaseous forms in the combustion process. As shown in Table 1, the raw materials contain $\mathrm{CaO}, \mathrm{SiO}_{2}, \mathrm{Al}_{2} \mathrm{O}_{3}$, and $\mathrm{Fe}_{2} \mathrm{O}_{3} . \mathrm{CaO}$ and $\mathrm{Fe}_{2} \mathrm{O}_{3}$ capture $\mathrm{CrOOH}$ in flue gas through Eq. (3) and Eq. (4), respectively, thereby lowering the efficiency of Cr volatilization (Li et al. 2018b). Chen et al.(Chen et al. 2013) studied the capture of $\mathrm{Cr}$ by additives during oxy-fuel combustion and observed that $\mathrm{CaO}$ could capture chromium steam and promote the enrichment of chromium in solid ash.

$$
\mathrm{CaO}+2 \mathrm{CrOOH}(\mathrm{g}) \rightarrow \mathrm{CaCr}_{2} \mathrm{O}_{4}+\mathrm{H}_{2} \mathrm{O}
$$

$$
\mathrm{Fe}_{2} \mathrm{O}_{3}+4 \mathrm{CrOOH}(\mathrm{g}) \rightarrow 2 \mathrm{FeCr}_{2} \mathrm{O}_{4}+1 / 2 \mathrm{O}_{2}(\mathrm{~g})+2 \mathrm{H}_{2} \mathrm{O}
$$

In addition, Wang et al.(Wang et al. 2012) studied the collection of heavy metals by different additives during the incineration of waste in a tube furnace, and observed the promoting effect of $\mathrm{SiO}_{2}$ and $\mathrm{Al}_{2} \mathrm{O}_{3}$ on capturing heavy metals. They(Wang et al. 2012) also observed that the heavy metal concentration in bottom ash reached a maximum value when the $\mathrm{Si}: \mathrm{Al}$ atomic ratio was $3: 1$, increasing the $\mathrm{Cr}$ capture from $40 \%$ to $79 \%$. In our experiments, the $\mathrm{Si}: \mathrm{Al}$ atomic ratio in the raw materials was approximately $3: 1$, so Cr volatilization is reduced.

Together, these results indicate that only a small amount of $\mathrm{Cr}$ is volatilized into the flue gas and therefore can be ignored in future experiments. 


\subsubsection{Migration and conversion of $\mathrm{Cr}$}

The $\mathrm{Cr}(\mathrm{VI})$ concentration in the raw materials and combustion products is shown in Table 6 . The $\mathrm{Cr}(\mathrm{VI})$ concentration in the clinker was increased significantly compared with the raw materials during all experimental conditions. The increased $\mathrm{Cr}(\mathrm{VI})$ concentration can be explained as follows: (1) $\mathrm{Cr}(\mathrm{VI})$ concentration increased under the influence of weight loss and (2) $\mathrm{Cr}(\mathrm{III})$ was oxidized to $\mathrm{Cr}(\mathrm{VI})$ during calcination.

Table 6 The total $\mathrm{Cr}(\mathrm{VI})$ concentration in raw materials and combustion products $(\mathrm{mg} / \mathrm{kg})$

\begin{tabular}{clll}
\hline \multirow{2}{*}{$\begin{array}{c}\text { Working } \\
\text { conditions }\end{array}$} & \multicolumn{2}{l}{ Raw materials } & Products \\
\cline { 2 - 4 } & Raw meal & Soil & Clinker \\
\hline Control & 0.66 & - & 10.97 \\
Add 1\% soil & 1.14 & 4.21 & 15.91 \\
Add 3\% soil & 0.78 & 4.21 & 20.90 \\
Add 5\% soil & 0.79 & 4.21 & 34.46 \\
\hline
\end{tabular}

The mass distribution of $\mathrm{Cr}(\mathrm{III})$ and $\mathrm{Cr}(\mathrm{VI})$ in raw materials and combustion products is shown in Fig.3. The ratio of $\mathrm{Cr}(\mathrm{VI})$ to total $\mathrm{Cr}$ was between $1.71 \%-5.21 \%$ in the raw materials, and between $38.66 \%-45.61 \%$ in the clinker. On average, $45.15 \%$ of the $\mathrm{Cr}(\mathrm{III})$ in the raw materials was oxidized.

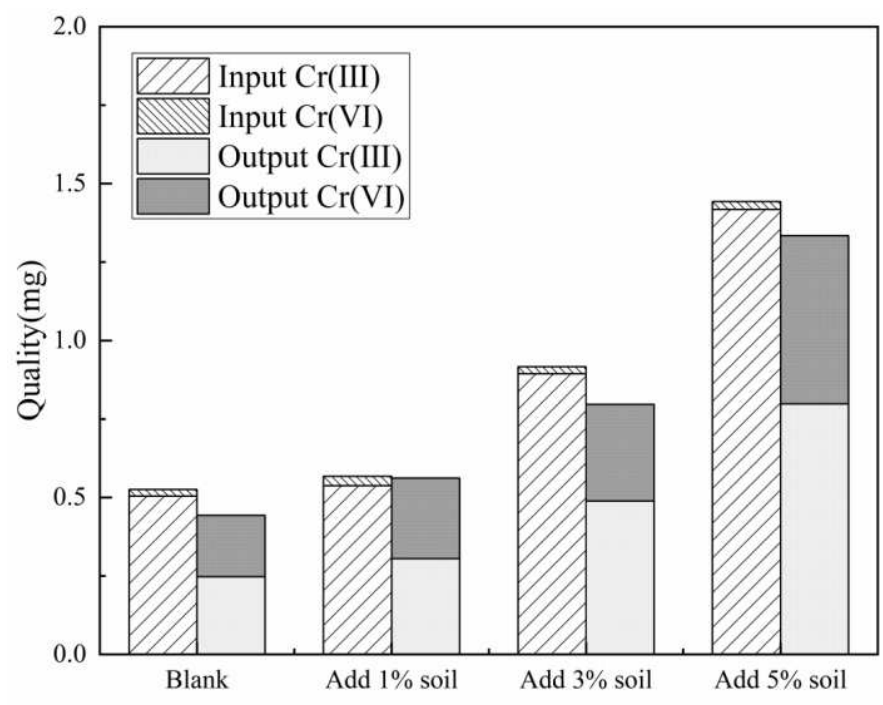

Working condition

Fig.3 The mass distribution of $\mathrm{Cr}(\mathrm{III})$ and $\mathrm{Cr}(\mathrm{VI})$ in raw materials and combustion products under different experimental conditions

$\mathrm{CaO}$ promotes the oxidation of $\mathrm{Cr}(\mathrm{III})$ to $\mathrm{Cr}(\mathrm{VI})$ according to Eq. (5) below. $\mathrm{CaO}$ may also promote the formation of unstable $\mathrm{CaCr}_{2} \mathrm{O}_{4}$, while $\mathrm{CaCr}_{2} \mathrm{O}_{4}$ is oxidized to $\mathrm{CaCrO}_{4}$ requiring less energy, as shown by Eq. (6) and Eq. (7) (Chen et al. 2012). $\mathrm{CaO}$ is converted to $\mathrm{Ca}^{0}$ by assisting the electron transfer from $\mathrm{Cr}$ (III) to $\mathrm{O}_{2}$, and $\mathrm{Ca}^{0}$ is then oxidized by $\mathrm{O}_{2}$ to $\mathrm{Ca}^{2+}$ (Chen et al. 2013). Verbinnen et al. (Verbinnen et al. 2013) studied the oxidation of $\mathrm{Cr}$ (III) during the heating of $\mathrm{Cr}_{2} \mathrm{O}_{3}$ and $\mathrm{CaO}$ at temperatures between $100^{\circ} \mathrm{C}$ and $1100^{\circ} \mathrm{C}$ and observed that $\mathrm{Cr}(\mathrm{III})$ was oxidized, which is consistent with the thermodynamic calculation. 


$$
\mathrm{Cr}_{2} \mathrm{O}_{3}+2 \mathrm{CaO}+1.5 \mathrm{O}_{2} \rightarrow 2 \mathrm{CaCrO}_{4}
$$

$$
\mathrm{Cr}_{2} \mathrm{O}_{3}+\mathrm{CaO} \rightarrow \mathrm{CaCr}_{2} \mathrm{O}_{4}
$$

$$
\mathrm{CaCr}_{2} \mathrm{O}_{4}+\mathrm{CaO}+1.5 \mathrm{O}_{2} \rightarrow 2 \mathrm{CaCrO}_{4}
$$

As shown in Eqs. (8) to (10), $\mathrm{CaCrO}_{4}$ dissociates into cations and $\mathrm{CrO}_{4}{ }^{2-}$ as the temperature increases, and $\mathrm{CrO}_{4}{ }^{2-}$ easily dissociates into $\mathrm{CrO}_{3}$ and $\mathrm{O}^{2-} . \mathrm{CrO}_{3}$ is thermodynamically unstable and dissociates into $\mathrm{Cr}_{2} \mathrm{O}_{3}$ and $\mathrm{O}_{2}$ at $500{ }^{\circ} \mathrm{C}$ (Mao et al. 2016). The free cations and $\mathrm{O}^{2-}$ are captured by $\mathrm{SiO}_{2}, \mathrm{Al}_{2} \mathrm{O}_{3}$, and $\mathrm{Fe}_{2} \mathrm{O}_{3}$ to form stable silicates, aluminates, and ferrites (Eqs. [11] to [13]). Mao et al. (Mao et al. 2016) believed that the potential of the metal oxides to promote $\mathrm{Cr}(\mathrm{VI})$ reduction was caused by their ability to combine with $\mathrm{O}^{2-}$. $\mathrm{SiO}_{2}$ is an acidic oxide, while $\mathrm{Al}_{2} \mathrm{O}_{3}$ and $\mathrm{Fe}_{2} \mathrm{O}_{3}$ are neutral oxides. $\mathrm{SiO}_{2}$ is more acidic than $\mathrm{Al}_{2} \mathrm{O}_{3}$ and $\mathrm{Fe}_{2} \mathrm{O}_{3}$ and can more easily combine with $\mathrm{O}^{2-}$ and therefore can promote $\mathrm{Cr}(\mathrm{VI})$ reduction. In addition, Mao et al. (Mao et al. 2016)studied the fate of $\mathrm{Cr}(\mathrm{VI})$ in the presence of $\mathrm{SiO}_{2}, \mathrm{Al}_{2} \mathrm{O}_{3}$, and $\mathrm{Fe}_{2} \mathrm{O}_{3}$ and observed that $\mathrm{SiO}_{2}$ can cause the release of $\mathrm{CaCrO}_{4}, \mathrm{Na}_{2} \mathrm{CrO}_{4}$, and $\mathrm{K}_{2} \mathrm{CrO}_{4}$ at around $900{ }^{\circ} \mathrm{C}, 1000{ }^{\circ} \mathrm{C}$, and $1000{ }^{\circ} \mathrm{C}$, respectively, while $\mathrm{Al}_{2} \mathrm{O}_{3}$ and $\mathrm{Fe}_{2} \mathrm{O}_{3}$ could only promote the reduction of $\mathrm{CaCrO}_{4}$.

Therefore, $\mathrm{SiO}_{2}, \mathrm{Al}_{2} \mathrm{O}_{3}$, and $\mathrm{Fe}_{2} \mathrm{O}_{3}$ can promote $\mathrm{Cr}(\mathrm{VI})$ reduction to different degrees.

$$
\mathrm{CaCrO}_{4} \rightarrow \mathrm{Ca}^{2+}+\mathrm{CrO}_{4}^{2-}
$$

$$
2 \mathrm{CaCrO}_{4}+2 \mathrm{SiO}_{2} \rightarrow 2 \mathrm{CaSiO}_{3}+\mathrm{Cr}_{2} \mathrm{O}_{3}+1.5 \mathrm{O}_{2}
$$

$$
2 \mathrm{CaCrO}_{4}+2 \mathrm{Al}_{2} \mathrm{O}_{3} \rightarrow 2 \mathrm{CaAl}_{2} \mathrm{O}_{4}+\mathrm{Cr}_{2} \mathrm{O}_{3}+1.5 \mathrm{O}_{2}
$$

$$
2 \mathrm{CaCrO}_{4}+2 \mathrm{Fe}_{2} \mathrm{O}_{3} \rightarrow 2 \mathrm{CaFe}_{2} \mathrm{O}_{4}+\mathrm{Cr}_{2} \mathrm{O}_{3}+1.5 \mathrm{O}_{2}
$$

Based on the experimental results, the possible reactions of $\mathrm{Cr}$ compounds in the calcination experiment are shown in Fig.4. $\mathrm{CaO}$ is a basic oxide, while $\mathrm{SiO}_{2}, \mathrm{Al}_{2} \mathrm{O}_{3}$, and $\mathrm{Fe}_{2} \mathrm{O}_{3}$ are acidic or neutral oxides. The two have opposite effects on the conversion of $\mathrm{Cr}$ valence.

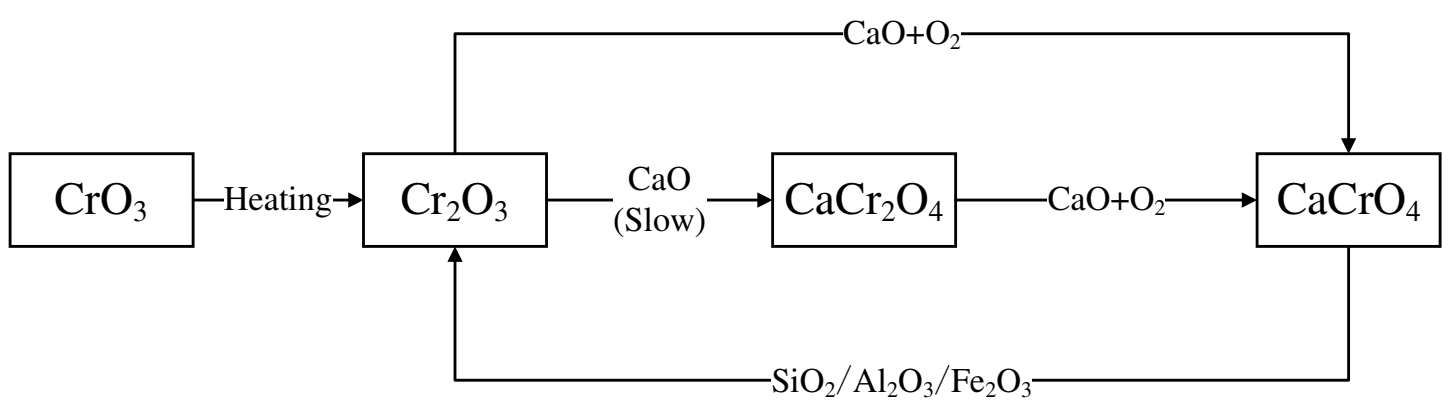

Fig.4 The possible reactions of $\mathrm{Cr}$ compounds in the calcination experiment 


\subsubsection{Mass balance of $\mathbf{C r}$}

The material streams for the combustion experiment of chrome-polluted soil in a cement rotary kiln are shown in Fig.5. The raw materials included cement raw meal, soil, coal, and kiln dust, and the combustion products included clinker, flue gas, and kiln dust. The $\mathrm{Cr}$ mass balance calculation was carried out based on these material streams. The kiln ash was returned to the kiln and therefore not included in the mass balance calculation. The input and output rates of $\mathrm{Cr}$ were calculated according to Tables 2 and 7, as shown in Table 8. Similar to Eq. (2), the mass balance rate of $\mathrm{Cr}$ was $110 \%$ for the control condition and $84 \%$ with $1 \%$ chrome-polluted soil. The mass balance results ranged from $70 \%$ to $130 \%$; therefore, the $\mathrm{Cr}$ is mass balanced and is not significantly volatilized into the flue gas. This is consistent with the results of the laboratory experiments.

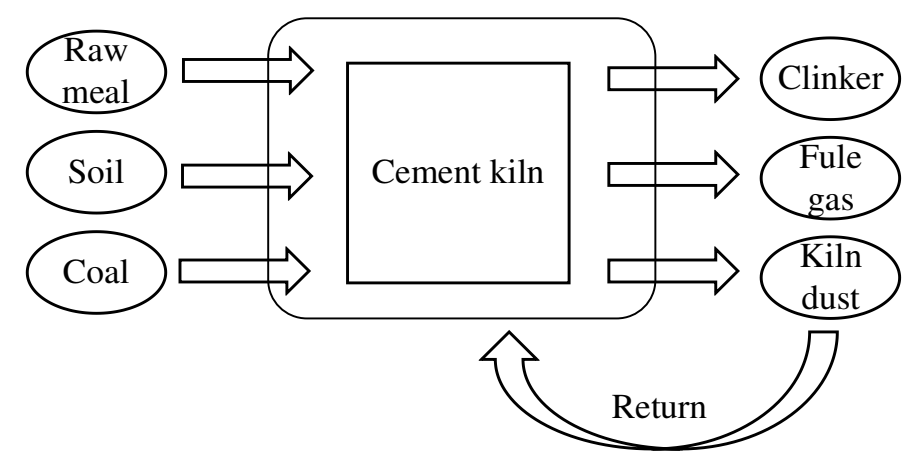

Fig.5 The material streams in the field-scale experiments

Table 7 Total $\mathrm{Cr}$ and $\mathrm{Cr}(\mathrm{VI})$ concentration in raw materials and products $(\mathrm{mg} / \mathrm{kg})$

\begin{tabular}{|c|c|c|c|c|c|}
\hline \multirow[t]{3}{*}{ Element } & \multirow[t]{3}{*}{ Conditions } & \multicolumn{3}{|c|}{ Raw materials } & \multirow{3}{*}{$\frac{\text { Products }}{\text { Clinker }}$} \\
\hline & & Raw & Soil & Coal & \\
\hline & & \multicolumn{3}{|c|}{ neal } & \\
\hline \multirow[t]{3}{*}{ Total Cr } & Control & 13.16 & - & 27.66 & 27.80 \\
\hline & Add $\quad 1 \%$ & 18.13 & 761.67 & 32.14 & 39.06 \\
\hline & & & & & \\
\hline \multirow[t]{2}{*}{$\mathrm{Cr}(\mathrm{VI})$} & Control & 1.27 & - & - & 24.73 \\
\hline & Add $\quad 1 \%$ & 0.86 & 4.21 & 0.44 & 34.16 \\
\hline
\end{tabular}

Table 8 Input and output rates of total $\mathrm{Cr}(\mathrm{g} / \mathrm{h})$

\begin{tabular}{lllll}
\hline Conditions & \multicolumn{2}{l}{ Raw materials } & & Products \\
\cline { 2 - 5 } & Raw meal & Soil & Coal & Clinker \\
Control & 2368.80 & - & 464.69 & 3108.04 \\
Add 1\% soil & 3263.40 & 1371.01 & 539.90 & 4366.91 \\
\hline
\end{tabular}

\subsubsection{Migration and conversion of $\mathrm{Cr}$}

Fig.6 shows the valence distribution of $\mathrm{Cr}$ in the cement kiln system for the control condition and with $1 \%$ chrome-polluted soil. In Fig.6, the distribution of $\mathrm{Cr}(\mathrm{III})$ and $\mathrm{Cr}(\mathrm{VI})$ in clinker under the control condition was almost the same as that with $1 \%$ chrome-polluted soil. The ratio of $\mathrm{Cr}(\mathrm{VI})$ to total $\mathrm{Cr}$ was $88.96 \%$ and $87.46 \%$, respectively, for the control and experimental conditions. On 
average, $87.94 \%$ of the $\mathrm{Cr}(\mathrm{III})$ in the raw materials was oxidized. In the laboratory experiments, the ratio of $\mathrm{Cr}(\mathrm{VI})$ to total $\mathrm{Cr}$ in the clinker ranged from $38.66 \%$ to $45.61 \%$. This is significantly lower than for the field-scale experiments, and can be explained by the different calcination conditions. The materials in the cement rotary kiln can make full contact with oxygen, while in a tube furnace, the inside of the bulk material does not have full contact with oxygen.

With the added $1 \%$ chrome-polluted soil, the $\mathrm{Cr}$ concentration in the clinker was higher than in the blank condition. Total $\mathrm{Cr}$ increased by $40.5 \%$, and $\mathrm{Cr}(\mathrm{VI})$ increased by $38.13 \%$. The increase in $\mathrm{Cr}$ can be explained by the addition of $1 \%$ chrome-polluted soil.
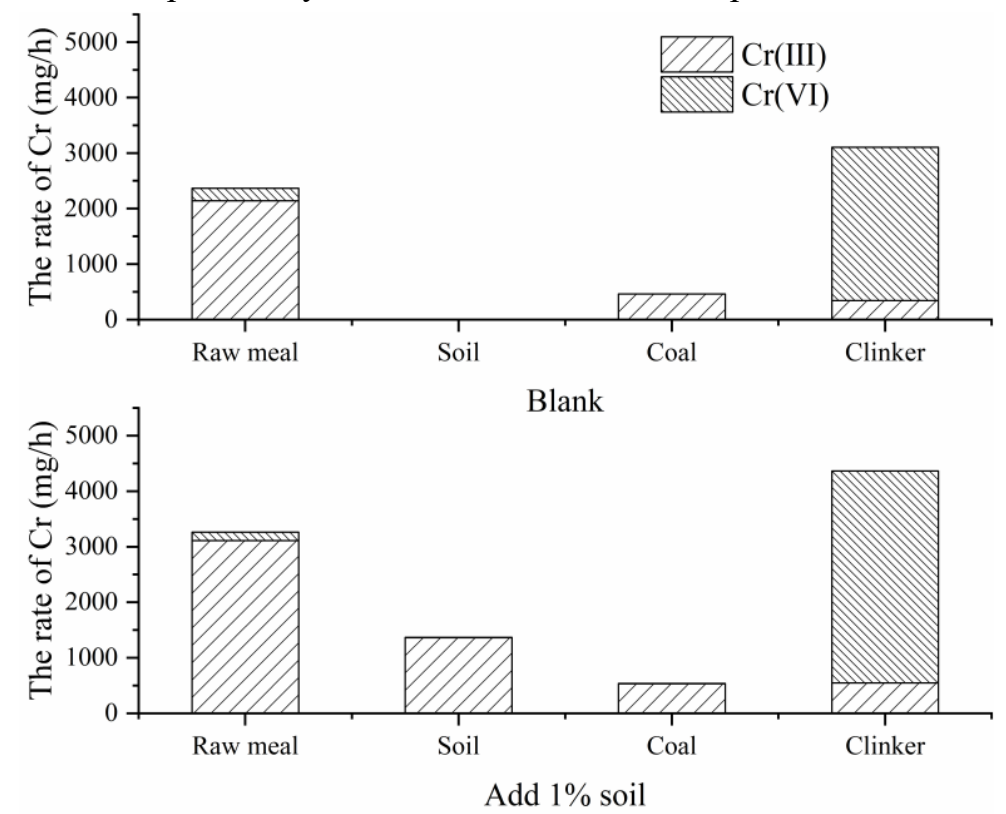

Fig.6 The valence distribution of $\mathrm{Cr}$ in the cement kiln under the control condition and with $1 \%$ chrome-polluted soil

\subsubsection{Possible reactions of $\mathrm{Cr}$ in the cement kiln}

The calcination process of raw meal in a cement kiln includes preheating, decomposition, sintering, and cooling, which are carried out in preheater, pre-calciner, rotary kiln, and clinker cooler, respectively. Based on the chemical reactions and reaction conditions of raw meal in a cement kiln, the possible reactions of $\mathrm{Cr}$ were analyzed in this study.

During preheating, the raw meal is heated to approximately $750{ }^{\circ} \mathrm{C}$, resulting in evaporation of water and dehydration and decomposition of the clay particles. First, the raw meal is dried, and the free water in raw meal evaporates at $100-150{ }^{\circ} \mathrm{C}$, increasing the $\mathrm{Cr}$ concentration in the raw meal. At around $450^{\circ} \mathrm{C}$, kaolin - the main component of clay-is dehydrated and decomposed into free $\mathrm{Al}_{2} \mathrm{O}_{3}$ and $\mathrm{SiO}_{2}$ (Eq. 14). $\mathrm{Al}_{2} \mathrm{O}_{3}$ and $\mathrm{SiO}_{2}$ inhibit the oxidation of $\mathrm{Cr}$ according to the thermodynamic equilibrium equation, which is consistent with the experimental results of Mao et al. (Mao et al. 2016).

$$
\mathrm{Al}_{2} \mathrm{O}_{3} \mathrm{~g} 2 \mathrm{SiO}_{2} \mathrm{~g} 2 \mathrm{H}_{2} \mathrm{O} \rightarrow \mathrm{Al}_{2} \mathrm{O}_{3}+2 \mathrm{SiO}_{2}+2 \mathrm{H}_{2} \mathrm{O}
$$

The temperature of the materials can reach approximately $870{ }^{\circ} \mathrm{C}$ in the pre-calciner, where limestone is decomposed; here, approximately $90 \%$ of the raw meal is decomposed. $\mathrm{CaCO}_{3}$ and $\mathrm{MgCO}_{3}$ are rapidly decomposed to free oxides and $\mathrm{CO}_{2}$ in the pre-calciner. The decomposition of $\mathrm{CaCO}_{3}$ is reversible, so ventilation of the pre-calciner is necessary to promote the emission of $\mathrm{CO}_{2}$. 
The pre-calciner is an oxidizing atmosphere where free $\mathrm{CaO}$ and $\mathrm{MgO}$ are extremely active and can react with $\mathrm{Cr}$.

In the pre-calcination process, a large amount of $\mathrm{CaO}$ promotes the oxidation of $\mathrm{Cr}$ (III) to $\mathrm{CaCrO}_{4}$ and rapidly oxidizes any $\mathrm{CaCr}_{2} \mathrm{O}_{4}$ to $\mathrm{CaCrO}_{4}$, as shown in Eqs. (5) to (7). Stam et al. (Stam et al. 2011) showed that the formation of $\mathrm{Cr}(\mathrm{VI})$ is a high-temperature process, and is affected by free $\mathrm{CaO}$ and the formation of solid chromate. Yang et al.(Yang et al. 2020a) studied the chromium speciation in chromium-rich tannery sludge under an air atmosphere at temperature of $300-1200^{\circ} \mathrm{C}$; they observed that $\mathrm{CaCrO}_{4}$ first appeared at $400{ }^{\circ} \mathrm{C}$, gradually increased in the range of $400-800{ }^{\circ} \mathrm{C}$, and reached a maximum at $800{ }^{\circ} \mathrm{C}$. This indicated the oxidation of $\mathrm{Cr}(\mathrm{III})$ to $\mathrm{Cr}$ (VI). Hu et al.(Hu et al. 2015) studied the distribution of $\mathrm{Cr}(\mathrm{VI})$ in municipal solid waste incineration ash and observed that the oxidation of $\mathrm{Cr}$ depended on the content of free $\mathrm{CaO}$. They(Hu et al. 2015) also studied the effect of temperature on the oxidation of $\mathrm{CaO}$ to $\mathrm{Cr}_{2} \mathrm{O}_{3}$ and observed that the maximum oxygen consumption rate was increased with increasing temperature from $700{ }^{\circ} \mathrm{C}$ to $900{ }^{\circ} \mathrm{C}$. This result indicated that $\mathrm{CaO}$ can promote the oxidation of most $\mathrm{Cr}(\mathrm{III})$ in this temperature range. In addition, $\mathrm{MgO}$ promotes the oxidation of $\mathrm{Cr}(\mathrm{III})$ into $\mathrm{MgCrO}_{4}$.

The solid-solid and sintering reactions occur in a rotary kiln. In the transition zone of the rotary kiln, at a temperature of $900-1150{ }^{\circ} \mathrm{C}$, free $\mathrm{CaO}, \mathrm{SiO}_{2}, \mathrm{Al}_{2} \mathrm{O}_{3}$, and $\mathrm{Fe}_{2} \mathrm{O}_{3}$ have multistage and complex solid reactions. $\mathrm{SiO}_{2}, \mathrm{Al}_{2} \mathrm{O}_{3}$, and $\mathrm{Fe}_{2} \mathrm{O}_{3}$ reduce $\mathrm{CaCrO}_{4}$, therefore inhibiting $\mathrm{Cr}(\mathrm{III})$ oxidation. In the sintering zone of the rotary kiln, a liquid phase will appear when the temperature of the materials rises to nearly $1300^{\circ} \mathrm{C}$. Because the melting point of $\mathrm{CaO}$ is $2570{ }^{\circ} \mathrm{C}$, most of $\mathrm{CaO}$ is still in the solid phase; however, $\mathrm{CaO}$ can dissolve in the high-temperature liquid( $\mathrm{Li} 2020$ ). Dissolved $\mathrm{CaO}$ has increased contact area with $\mathrm{Cr}$, promoting the oxidation of $\mathrm{Cr}$ to a certain extent. In the cooling process of clinker, there is still a small amount of free $\mathrm{CaO}$ in the solidified material that has not been chemically reacted.

\subsubsection{Environmental implications}

The distribution of $\mathrm{Cr}$ in two cement products ( $\mathrm{P} \cdot \mathrm{C} 32.5 \mathrm{R}$ and $\mathrm{P} \cdot \mathrm{C} 42.5 \mathrm{R}$ ) with added $1 \%$ chrome-polluted soil is shown in Table 9. The Cr concentration in the cement products was lower than that in the clinker, as shown in Table 7. The total $\mathrm{Cr}$ for the two cement products decreased by $40.14 \%$ and $8.09 \%$, and $\mathrm{Cr}(\mathrm{VI})$ fell by $61.59 \%$ and $62.64 \%$, respectively. The decrease occurred because the $\mathrm{Cr}$ concentration in clinker was diluted after adding gypsum, and other additives. The standard Gb30760-2014 "Technical Specification for Collaborative Disposal of Solid Waste by Cement Kiln" indicates that the limit for $\mathrm{Cr}$ in clinker is $150 \mathrm{mg} / \mathrm{kg}$. Therefore, adding $1 \%$ of chrome-polluted soil to the raw meal of a cement kiln conforms to Chinese safety standards.

Table 9 The distribution of $\mathrm{Cr}$ in two cement products $(\mathrm{mg} / \mathrm{kg})$

\begin{tabular}{lll}
\hline Elements & P.C 32.5R & P.C 42.5R \\
\hline Total Cr & 23.38 & 35.90 \\
$\mathrm{Cr}(\mathrm{VI})$ & 13.12 & 12.76 \\
\hline
\end{tabular}

\section{Conclusions}

For the four calcination experiments in a tube furnace, the $\mathrm{Cr}$ mass balance values ranged from $84 \%$ to $99 \%$, and the average mass balance was $91 \%$. During the co-processing of chrome-polluted soil with raw meal in a cement rotary kiln, the mass balance values were $110 \%$ and $84 \%$ in the 
control condition and with added 1\% chrome-polluted soil, respectively, for the two cement formulations used. Therefore, most of the $\mathrm{Cr}$ was fixed in the solid products, and very little $\mathrm{Cr}$ was volatilized into the flue gas. Most $\mathrm{Cr}$ compounds in the raw materials were difficult to volatilize. $\mathrm{Cr}$ hydroxides that may have been volatilized into the flue gas were captured by $\mathrm{CaO}$ and $\mathrm{Fe}_{2} \mathrm{O}_{3}$.

Most of the $\mathrm{Cr}(\mathrm{III})$ in the raw materials was oxidized to $\mathrm{Cr}(\mathrm{VI})$ after being calcined, and a higher proportion of $\mathrm{Cr}(\mathrm{III})$ was oxidized in cement kiln. The average concentration of total $\mathrm{Cr}$ was $403.25 \mathrm{mg} / \mathrm{kg}$, and the ratio of $\mathrm{Cr}(\mathrm{VI})$ to total $\mathrm{Cr}$ was $1.83 \%$ or less in the chrome-polluted soil samples. In laboratory experiments, the ratio of $\mathrm{Cr}(\mathrm{VI})$ to total $\mathrm{Cr}$ was between $38.66 \%$ and $45.61 \%$ in the clinker, and an average of $45.15 \%$ of $\mathrm{Cr}$ (III) in the raw materials was oxidized. In the fieldscale experiments, $87.94 \%$ of $\mathrm{Cr}$ (III) was oxidized. The oxidation of $\mathrm{Cr}$ (III) can be explained as follows: in a high-temperature and oxidizing atmosphere, large amounts of $\mathrm{CaO}$ and $\mathrm{MgO}$ promote the oxidation of $\mathrm{Cr}(\mathrm{III})$ to $\mathrm{Cr}(\mathrm{VI})$, while $\mathrm{SiO}_{2}, \mathrm{Al}_{2} \mathrm{O}_{3}$, and $\mathrm{Fe}_{2} \mathrm{O}_{3}$ promote $\mathrm{Cr}(\mathrm{VI})$ reduction, leading to the oxidation of most of the $\mathrm{Cr}(\mathrm{III})$. The materials in the cement rotary kiln have full contact with oxygen, while in the tube furnace, the inside of the materials does not have full contact with oxygen, resulting in a higher proportion of $\mathrm{Cr}(\mathrm{III})$ oxidized in the cement kiln.

In the cement kiln experiment with added $1 \%$ chrome-polluted soil, the $\mathrm{Cr}$ concentration in the two tested cement products was 23.38 and $35.90 \mathrm{mg} / \mathrm{kg}$, respectively, conforming to the Chinese safety standards. The co-processing technology poses no environmental risk at this lower mixing ratio.

Ethical Approval: Not applicable.

Consent to Participate: Not applicable.

Consent to Publish: Not applicable.

Authors Contributions: HPX designed the experiments and analyzed the transformation mechanism of chromium. YL and MWW analyzed the distribution of chromium systematically and were major contributors in writing the manuscript. DHY and ZL organized the experiments. All authors read and approved the final manuscript.

Funding: This study was supported by the National Natural Science Foundation of China (No. 51676070).

Competing Interests: The authors declare that they have no competing interests.

Availability of data and materials: The datasets used and analyzed during the current study are available from the corresponding author on reasonable request. 


\section{References}

Aranda Usón A, López-Sabirón AM, Ferreira G, Llera Sastresa E (2013) Uses of alternative fuels and raw materials in the cement industry as sustainable waste management options Renewable and Sustainable Energy Reviews 23:242-260 doi:10.1016/j.rser.2013.02.024

Chen J, Jiao FC, Zhang L, Yao H, Ninomiya Y (2012) Use of synchrotron XANES and Crdoped coal to further confirm the vaporization of organically bound $\mathrm{Cr}$ and the formation of chromium(VI) during coal oxy-fuel combustion Environ Sci Technol 46:3567-3573 doi:10.1021/es204255h

Chen J, Jiao FC, Zhang L, Yao H, Ninomiya Y (2013) Elucidating the mechanism of Cr(VI) formation upon the interaction with metal oxides during coal oxy-fuel combustion $\mathrm{J}$ Hazard Mater 261:260-268 doi:10.1016/j.jhazmat.2013.07.023

Fan XG, Yang YF, Huang QF, Li ZW, Yu HJ (2014) The transformation of Cr form at different temperatures in the co-treatment of $\mathrm{Cr}$ containing waste in cement kiln Research of Environmental Sciences 27:272-278 doi:10.13198/j.issn.1001-6929.2014.03.08

Fu LJ, Feng AX, Xiao JJ, Wu Q, Ye QY, Peng S (2021) Remediation of soil contaminated with high levels of hexavalent chromium by combined chemical-microbial reduction and stabilization Journal of Hazardous Materials 403 doi:10.1016/j.jhazmat.2020.123847

Gong HY et al. (2020) The potential oxidation characteristics of $\mathrm{CaCr} 2 \mathrm{O} 4$ during coal combustion with solid waste in a fluidized bed boiler: A thermogravimetric analysis Chemosphere 263:127974 doi:10.1016/j.chemosphere.2020.127974

Hu HY, Shi MY, Yang YH, Liu H, Xu M, Shen JH, Yao H (2018) Further Insight into the Formation and Oxidation of CaCr2O4 during Solid Fuel Combustion Environ Sci Technol 52:2385-2391 doi:10.1021/acs.est.7b05538

Hu HY, Xu Z, Liu H, Chen DK, Li AJ, Yao H, Naruse I (2015) Mechanism of chromium oxidation by alkali and alkaline earth metals during municipal solid waste incineration Proceedings of the Combustion Institute 35:2397-2403 doi:10.1016/j.proci.2014.08.029

Jiang XG, Dong H, Lv GJ, Chi Y, Yan JH (2016) Oxidation mechanism and control method of $\mathrm{Cr}$ during high temperature combustion Chemical Industry and Engineering Progress 35:110 doi:10.16085/j.issn.1000-6613.2016.s2.001

Kavouras P et al. (2015) Incineration of tannery sludge under oxic and anoxic conditions: Study of chromium speciation Journal of Hazardous Materials 283

Kosajan V, Wen Z, Fei F, Doh Dinga C, Wang Z, Zhan J (2020) The feasibility analysis of cement kiln as an MSW treatment infrastructure: From a life cycle environmental impact perspective Journal of Cleaner Production 267 doi:10.1016/j.jclepro.2020.122113

Li CP (2020) Practical technology for collaborative disposal of household garbage by cement kiln. vol 05. China Building Industry Press, Beijing

Li L, Huang QF, zhang ZQ, Cai ML, Yan DH (2009) Study on the pollution discharge of contaminated soil treated by cement kiln Chinese Journal of Environmental Engineering 3:891896

Li XY, Dong H, Chen J, Lu C, Luo G, Yao H (2018a) Transformation of Organically Bound Chromium during Oxy-coal Combustion: The Influence of Steam and Mineral Energy \& Fuels 32:1992-1998 doi:10.1021/acs.energyfuels.7b03123

Li XY, Dong H, Zhao XP, Chen J, Lu CM, Yao H (2018b) Effect of water vapor on mineral 
chromium capture under oxygen-enriched combustion CIESC Journal 69:2714-2721 doi:10.11949/j.issn.0438-1157.20171460

Mao LQ, Deng N, Liu L, Cui H, Zhang WY (2016) Effects of Al2O3, Fe2O3, and SiO2 on $\mathrm{Cr}(\mathrm{VI})$ formation during heating of solid waste containing $\mathrm{Cr}$ (III) Chemical Engineering Journal 304:216-222 doi:10.1016/j.cej.2016.06.086

Nowak B, Frías Rocha S, Aschenbrenner P, Rechberger H, Winter F (2012) Heavy metal removal from MSW fly ash by means of chlorination and thermal treatment: Influence of the chloride type Chemical Engineering Journal 179:178-185 doi:10.1016/j.cej.2011.10.077

Roy B, Choo WL, Bhattacharya S (2013) Prediction of distribution of trace elements under Oxy-fuel combustion condition using Victorian brown coals Fuel 114:135-142 doi:10.1016/j.fuel.2012.09.080

Stam AF, Meij R, Te Winkel H, Eijk RJ, Huggins FE, Brem G (2011) Chromium speciation in coal and biomass co-combustion products Environ Sci Technol 45:2450-2456 doi:10.1021/es103361g

Świetlik R, Trojanowska M, Łożyńska M, Molik A (2014) Impact of solid fuel combustion technology on valence speciation of chromium in fly ash Fuel 137:306-312 doi:10.1016/j.fuel.2014.08.010

Verbinnen B, Billen P, Van Coninckxloo M, Vandecasteele C (2013) Heating temperature dependence of $\mathrm{Cr}$ (III) oxidation in the presence of alkali and alkaline earth salts and subsequent Cr(VI) leaching behavior Environ Sci Technol 47:5858-5863 doi:10.1021/es4001455

Wang AY, Zhong GF, Xu GB, Liu ZX, Shen XB (2011) Effects of Chromium stress on physiological characteristics and Chromium enrichment of Mustard rapeseed Environmental Science 32:1717-1725

Wang WX, Hu HY, Zhu JJ, Yao H, XU MH, Qiao Y (2014) Study on the distribution and leaching characteristics of Chromium in waste incineration bottom ash Journal of Engineering Thermophysics 35:196-199

Wang XY, Huang YJ, Zhong ZP, Niu MM, Sun Y, Zhang Q (2012) Experimental study on the influence of additives on heavy metal collection in waste incineration Proceedings of the CSEE 32:15-21

Yang YL, Ma HR, Chen XP, Zhu C, Li XJ (2020a) Effect of incineration temperature on chromium speciation in real chromium-rich tannery sludge under air atmosphere Environ Res 183:109159 doi:10.1016/j.envres.2020.109159

Yang Z, Wang CX, Li YM, Yang S, Zhang W, Li YL (2020b) Assessing the chromium mobility in ashes through $\mathrm{SiO} 2-\mathrm{Al} 2 \mathrm{O} 3-\mathrm{Fe} 2 \mathrm{O} 3-\mathrm{CaO}$ system: The role of composition Chemosphere 257:127112 doi:10.1016/j.chemosphere.2020.127112 
Figures

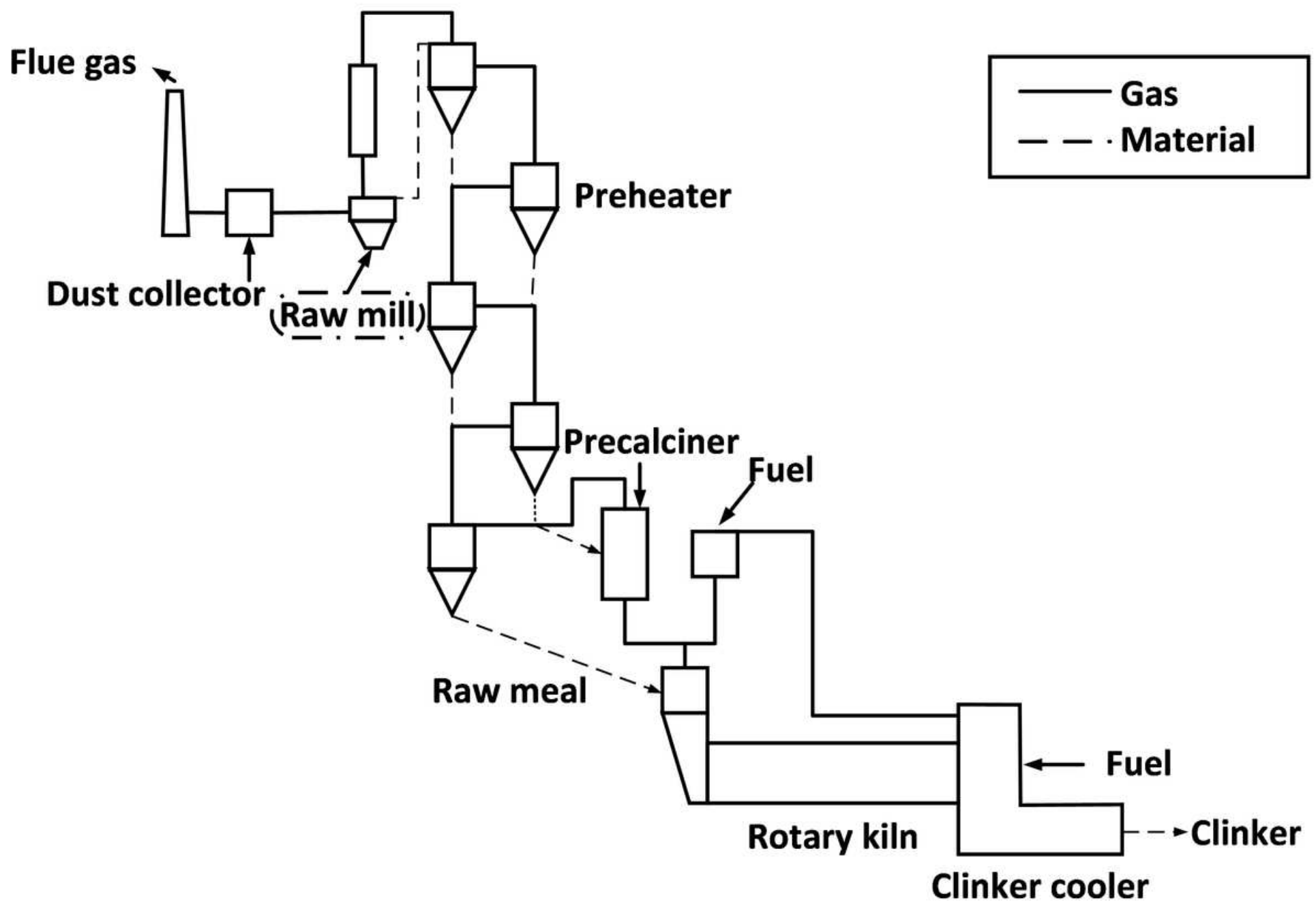

Figure 1

Schematic diagram of a cement kiln system 


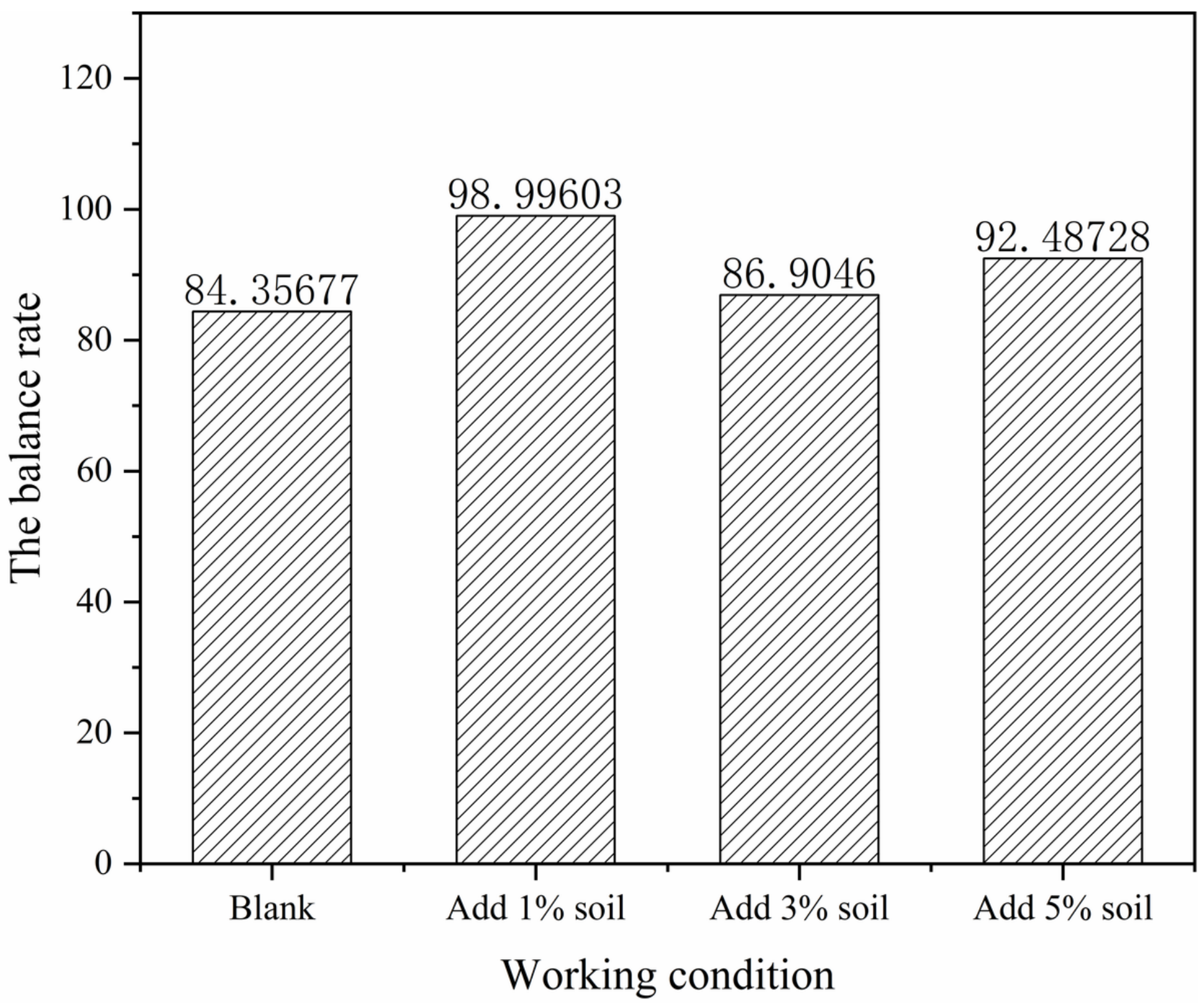

Figure 2

The mass balance value for $\mathrm{Cr}$ under different experimental conditions 


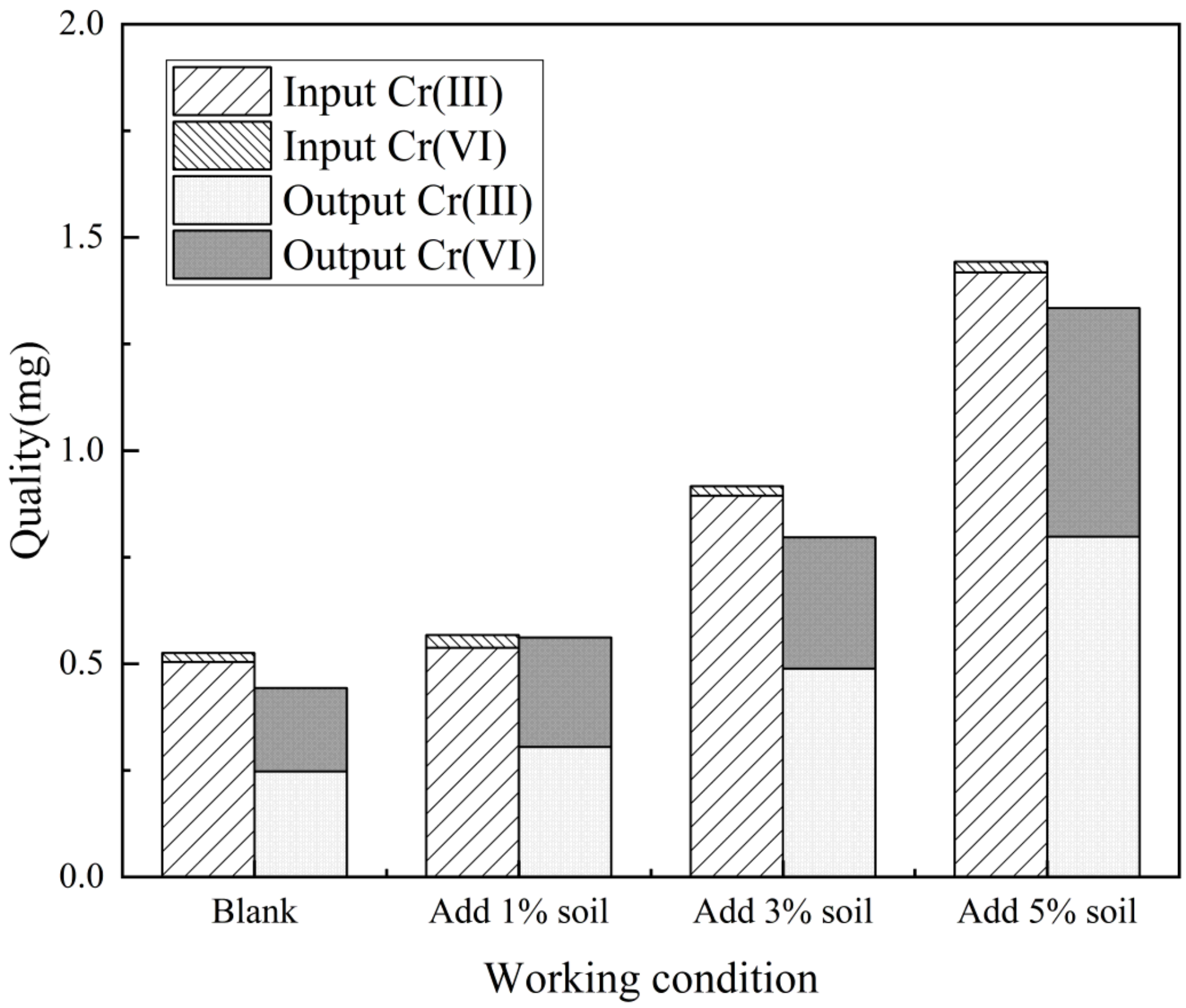

Figure 3

The mass distribution of $\mathrm{Cr}(\mathrm{III})$ and $\mathrm{Cr}(\mathrm{VI})$ in raw materials and combustion products under different experimental conditions

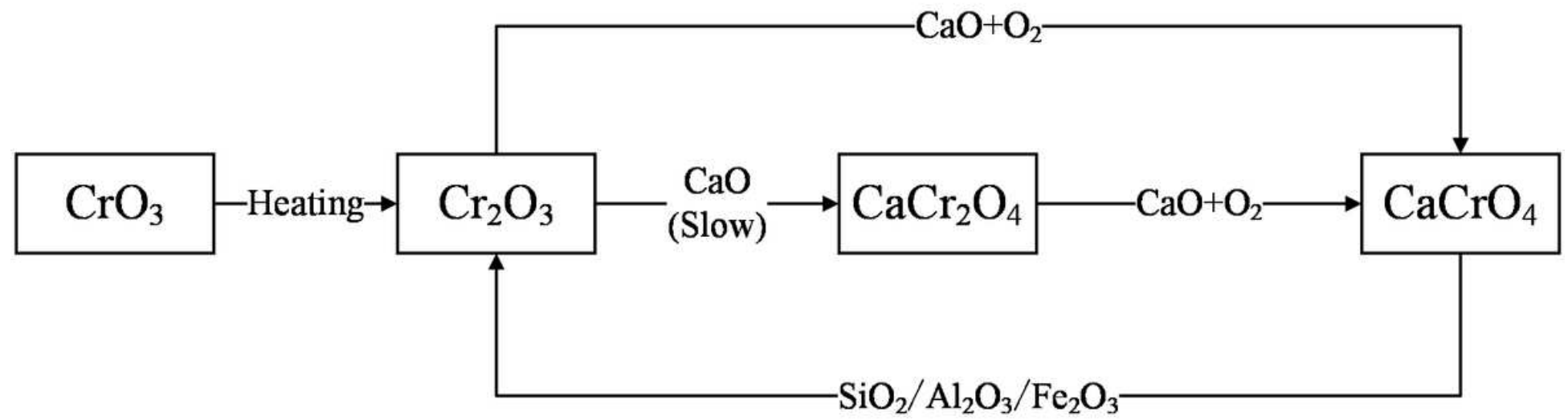


Figure 4

The possible reactions of $\mathrm{Cr}$ compounds in the calcination experiment

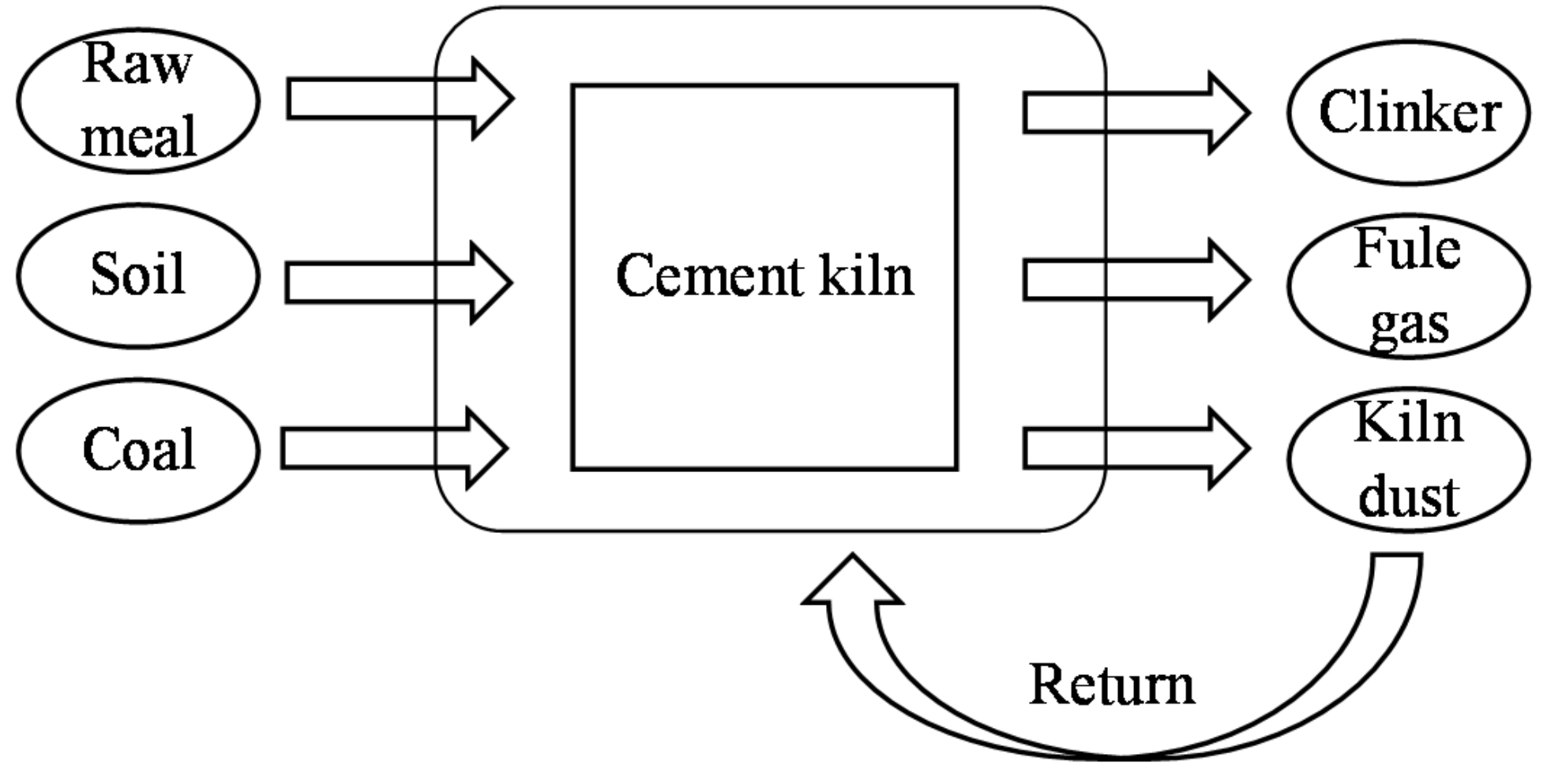

Figure 5

The material streams in the field-scale experiments 

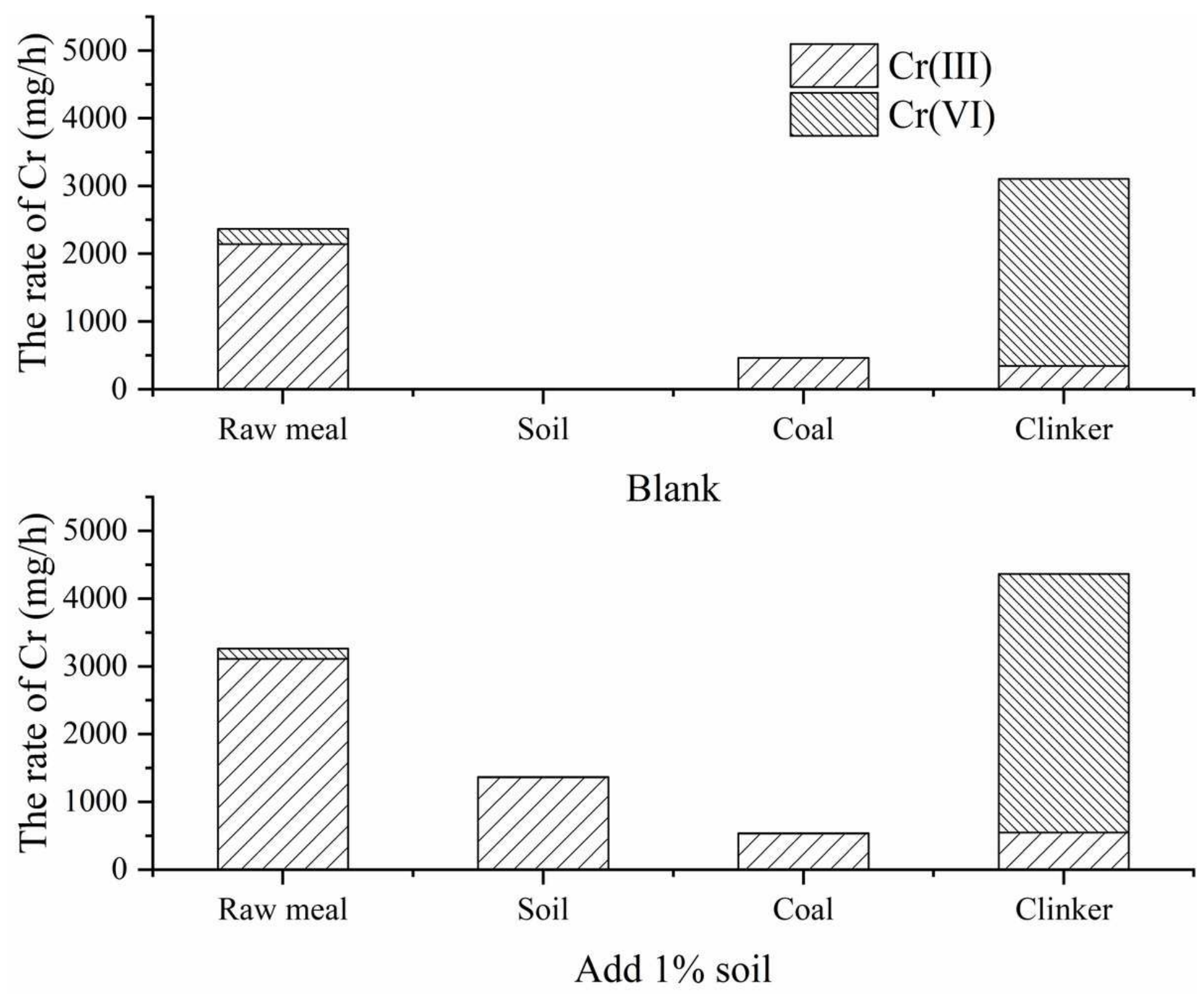

Figure 6

The valence distribution of $\mathrm{Cr}$ in the cement kiln under the control condition and with $1 \%$ chrome-polluted soil 